\title{
Disaster by design
}

One day a few weeks ago, around four o'clock in the afternoon local time, I stood in a small group of tourists about 200 metres from the imposing grey-black carcass of the infamous reactor number four of the Chernobyl nuclear power plant, two hours' drive north of Kiev, Ukraine. Twenty-six years ago, of course, this reactor blew up, and graphite from its interior ignited. The resulting fire burned for days and released large plumes of radioactive contamination that drifted in the atmosphere over the western USSR and Europe. The event killed 56 people directly, and several thousand of the more than 600,000 military reservists called in to remove debris died within a few years. Recent estimates put the number of cases of thyroid cancer ultimately caused by the incident at around 4,000 (although such estimates vary enormously).

The reactor today stands at the centre of an oblong exclusion zone - referred to by the military as the 'zone of mandatory resettlement' - with an approximate radius of 40 kilometres, entrance to which requires passage through two military checkpoints. In the days and weeks after the disaster, Soviet authorities evacuated more than 350,000 people from this zone, leading to the complete abandonment of more than 100 villages, which today remain empty, but for a few brave (or foolhardy) 'self-settlers' who have recently begun to return.

A few miles from the reactor, the town of Chernobyl, once home to more than 14,000 people, now houses workers who live in the zone on rotation. A handful of scientists and engineers monitor radiation levels and study the influence of radiation on the local wildlife; others work on the construction of the new sarcophagus for the reactor - a vast, arching structure that should be in place by 2016 . There are even a few tour guides living in Chernobyl, who are there to direct oddly motivated tourists such as myself and my friends.

Just in front of the reactor, a Geiger counter I held read about three microsieverts per hour. This is about ten times higher than the average radiation background on the Earth's surface, and some 100,000 times weaker than the level would have been just after the accident, before the reactor had been encased in a temporary tomb of steel and concrete. The area around the reactor is now completely safe for short visits, at least if you listen to

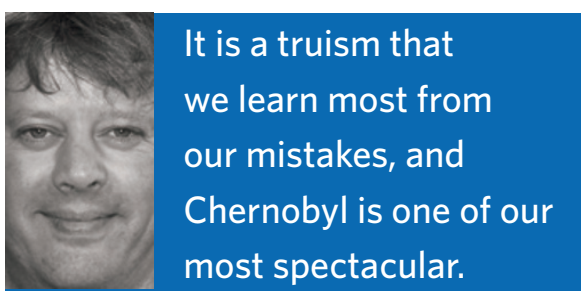

the advice of your guide and don't wander a few feet in any direction, as levels might suddenly spike 100 or 1,000 times higher: owing to prevailing winds at the time, rainfall, and the scattered burial sites of contaminated buildings and equipment, radiation levels can fluctuate wildly.

The zone is an eerie place. Just one kilometre from the reactor stands the ghost town of Prypiat, once a model Soviet town of nearly 60,000 people - most of whom worked at the reactor complex. It now resembles the set for a post-apocalyptic film. Dense thickets of poplars and other trees have grown up through the roads and walkways and now penetrate the buildings, which have begun to tumble down. Birds occupy the apartments in high-rise towers, whose windows stand open, interiors untouched since the moment the residents fled, leaving everything behind. Inside a school building, a poster on the wall celebrates the fortieth anniversary of Soviet victory in the Great Patriotic War against the Nazis (1945-1985).

But Chernobyl is more than a frightening novelty. It is a truism that we learn most from our mistakes, and Chernobyl is one of our most spectacular. The accident itself was a perfect illustration of the immense difficulty, indeed impossibility, of protecting against very rare and extreme risks.

Paradoxically, the disaster was triggered during what was meant to be a routine test of one of the reactor safety mechanisms.

Reactor engineers were worried about the ability of the reactor to avoid problems in the event of an electrical failure. By design, several diesel generators were supposed to provide power for the reactor cooling system in such an event, but tests had shown they took an unacceptably long 45 seconds to achieve sufficient power: engineers hoped to derive enough power in that interval by harnessing the inertia from the reactor's own turbine as it slowed.

To conduct a test, some of the reactor's safety mechanisms had to be shut down.
By bad luck and a conspiracy of accidents, the test finally ended up being conducted at $1 \mathrm{am}$, with the reactor operating well outside intended safety parameters. As a result, when things did go wrong, other safety mechanisms - such as the insertion of control rods - actually caused a momentary spike in reactor power before having the desired slowing effect. By then it was too late. The first explosion had already taken place.

Despite all efforts, our human habits of thinking and practice always create weak spots. The sociologist Diane Vaughan refers to the process as the 'normalization of deviance' - reassured by the absence of disaster, people quite naturally allow boundaries of accepted practice to drift gradually. Absence of disaster is taken as evidence of continued safety, until the event finally strikes. When the reactor runs safely outside the prescribed operating boundaries 100 times in a row, why not do it again?

But the other lesson of Chernobyl is more positive. Nature is, at least in some cases, far more resilient than we typically think. Animals in the region certainly are affected by the radiation. A study a few years ago, for example, found that birds in the region had systematically smaller brains than birds outside the zone - an effect possibly caused by a high frequency of radiation-induced developmental errors.

However, the dramatic reduction of human activity in the region has been equally beneficial. Large animals such as bison and wolves had been eliminated from the region by the early twentieth century, but they have now returned, as have other large mammals such as elk, moose and wild pigs. Scientists monitoring the wolves find significant levels of radiation in their tissues, yet the population seems to be thriving nonetheless. Even in the heavily contaminated area of the Red Forest - a pine forest that turned red and died just after the event - a range of small mammals and birds now seem to be more populous than in clean regions outside of the exclusion zone.

Creating a nuclear wasteland may not be the best approach to ecological preservation, but nature can handle more than we might expect.

MARK BUCHANAN 